\title{
Effects of GnRH and anti-PMSG injections on fertility in ewes pre-treated with MAP sponge and PMSG during the non-breeding season
}

\author{
Yutaka Fukui, Shinji Takenaka, Ikuo DomeKi* \\ and Hitoshi ONO \\ Department of Meat Animal Reproduction, Obihiro University of Agriculture and \\ Veterinary Medicine, Obihiro 080 and $*$ Department of Animal Reproduction, \\ National Institute of Animal Husbandry, Ibaraki 305
}

\begin{abstract}
Summary. Effects of synthetic gonadotropin releasing hormone $(\mathrm{GnRH})$ and rabbit antipregnant mare serum gonadotropin (PMSG) on numbers of ovulation, fertility and prolificacy were investigated in 59 Suffolk ewes in which estrus was induced by a progestin (methyl. acetoxyprogesterone: MAP)-impregnated vaginal sponge and 750 IU PMSG during anestrous season. The animals, at the time of estrus, were administered intramuscularly either with saline (group I), $150 \mu \mathrm{g} \mathrm{GnRH} \mathrm{(group} \mathrm{II),} \mathrm{or} \mathrm{rabbit} \mathrm{anti-PMSG} \mathrm{serum} \mathrm{that} \mathrm{could} \mathrm{neutralize} \mathrm{the}$ potency of $750 \mathrm{IU}$ PMSG (group III) and artificially inseminated. A total of 56 ewes (group I: 18, group II: 19 and group III: 19) were inseminated with fresh-undiluted semen.. Although pregnancy rates were not significantly different among these groups, lambing rate in group II $(57.9 \%)$ was significantly higher than group I $(16.7 \%: P<0.01)$ and Group III $(26.3 \%: P<0.05)$. Prolificacy were not significantly different among the groups $(1.67 \pm 0.58,1.19 \pm 0.83$ and $2.20 \pm$ 0.84 for groups I, II and III, respectively). Numbers of ovulations and follicles of $>5 \mathrm{~mm}$ in diameter, examined at the 8th day after PMSG treatment in 10 ewes per group, were also not significantly different among the groups. However, wastage proportion of eggs or embroys significantly $(P<0.025)$ decreased in $\mathrm{GnRH}$-injected ewes $(64.3 \%)$ as compared with that in saline-treated ewes $(90.0 \%)$. A decrease in the plasma concentration of estradiol-17 $\beta$, caused by anti-PMSG treatment did not improve the fertility. These results indicate that a single intramuscular injection of GnRH at the onset of estrus, induced with MAP sponge and PMSG treatments, was effective for improvement of fertility in ewes during non-breeding season.
\end{abstract}

(Japan. J. Anim. Reprod., 30, 108-116, 1984)

\section{Introduction}

Although pregnant mare serum gonadotropin (PMSG) with a progestin pretreatment has been widely used for induction of estrus and ovulation in seasonally anestrous ewes, the fertility in these animals is not satisfactory ${ }^{1,2)}$. Recently the use of synthetic gonadotropin releasing hormone $(\mathrm{GnRH})$ has been attempted to induce a fertile estrus in ewes during the non-breeding season ${ }^{3-6)}$. It has been also reported that anti-PMSG decreases the prolonged high blood concen- tration of estradiol-17ß $\left(\mathrm{E}_{2}\right)$, which has been maintained by PMSG remaining in the blood because of its long half life, and neutralizes the effect of PMSG administered for follicular growth and ovulation in sheep ${ }^{7)}$, goates ${ }^{9}$ and cattle $^{9)}$. The present study was conducted to investigate the effects of $\mathrm{GnRH}$ and antiPMSG injections on fertility at the induced estrus following progestin (methyl-acetoxyprogesterone: MAP)-impregnated vaginal sponge and PMSG treatments in seasonally anestrous ewes. 


\section{Materials and Methods}

The present study was conducted from April to June, 1983 during the non-breeding season. The vaginal sponge containing $60 \mathrm{mg}$ MAP (Upjohn International Ltd., Australia) was inserted into vagina for 9 days in 59 mature (2-6 years old) Suffolk ewes. The animals had been kept in the D-type house with the yard during the study. They were fed one kg hay per head (given twice daily) and a concentrate pellet containing $15 \%$ crude protein (about $200 \mathrm{~g}$ per head per day), and allowed free access to water, salt and mineral blocks. At the sponge removal, all ewes were given an intramuscular injection of $750 \mathrm{IU}$ PMSG and run with four teasing rams fitted with marking-harnesses and crayons, and an abdominal apron to prevent copulation. Estrus was examined $6 \mathrm{~h}$ intervals for 5 days after PMSG treatment. At the time of estrus detection, ewes were injected intramuscularly with $2 \mathrm{~m} l$ of saline (control: group I), $3 \mathrm{~m} l$ $(150 \mu \mathrm{g}) \mathrm{GnRH}$ solution (Conceral, Takeda Industrial Co., Japan: group II), or $2 \mathrm{~m} l$ of rabbit anti-PMSG serum diluted with $0.9 \%$ (v/v) physiological saline to neutralize $750 \mathrm{IU}$ PMSG (Teikoku-zoki Co., Japan: group III). One $\mathrm{m} l$ of the original rabbit anti-PMSG used in the present study has been demonstrated to neutralize 35,800 IU of PMSG. Estrous ewes were artificially inseminated $9 \mathrm{~h}$ later with $0.2-0.25 \mathrm{~m} l$ of fresh-undiluted semen containing at least $300 \times 10^{6}$ motile spermatozoa. Ten ewes in each group were laparotomized to examine numbers of ovulations and follicles of $>5 \mathrm{~mm}$ in diameter 8 days after PMSG treatment. In the laparotomized ewes, wastage proportions of eggs or embryos were caluculated by the formula ${ }^{10)}$ of 1 -(no. of lambs born/no. of ovulations for ewes conceiving at first estrus) $\times 100$. Pregnancy was detected by using an ultrasonic Doppler method 70-90 days after insemination. Fertility was expressed as pregnancy and lambing, and prolificacy (no. of lambs born/ no. of ewes lambing) was also examined.

Blood was collected from the jugular vein using heparinized test-tubes in 5 ewes of each group. Plasma was separated by centrifugation at 3,000 rpm for 10 minutes and stored at $-20 \mathrm{C}$ until mesurement. Plasma samples were taken at 6 or $12 \mathrm{~h}$ intervals for 5 days after PMSG treatment for $\mathrm{E}_{2}$ and luteinizing hormone $(\mathrm{LH})$, and at $8,14,18$ and 22 days thereafter for progesterone $(\mathrm{P})$. Plasma $\mathrm{E}_{2}$ and $\mathrm{P}$ concentrations were measured by radioimmunoassay (RIA) according to the

Table 1. Effects of GnRH and anti-PMSG on fertility of ewes pretreated with MAP sponge and PMSG during the non-breeding season

\begin{tabular}{|c|c|c|c|c|c|c|}
\hline Group & $\begin{array}{l}\text { Additional } \\
\text { treatment }\end{array}$ & $\begin{array}{c}\text { No. of ewes } \\
\text { treated }\end{array}$ & $\begin{array}{l}\text { No. of ewes } \\
\text { in estrus } \% \\
\text { inseminated }\end{array}$ & $\underset{(\%)}{\text { Pregnant }}$ & $\underset{(\%)}{\text { Lambing }}$ & $\begin{array}{r}\text { Prolificacy } \\
(\text { Mean } \pm \text { SD })\end{array}$ \\
\hline I & Saline & $19 *$ & 18 & $\begin{array}{c}5 \\
(27.8)^{\mathrm{a}}\end{array}$ & ${ }^{3}{ }^{3}$ & $1.67 \pm 0.58^{a}$ \\
\hline II & $\mathrm{GnRH}$ & 20 & 19 & $\begin{array}{c}11 \\
(57.9)^{\mathrm{a}}\end{array}$ & $\begin{array}{c}11 \\
(57.9)^{\mathrm{b}}\end{array}$ & $1.91 \pm 0.83^{\mathrm{a}}$ \\
\hline III & Anti-PMSG & 20 & 19 & $\begin{array}{c}7 \\
(36.8)^{\mathrm{a}}\end{array}$ & $\begin{array}{c}5 \\
(26.3)^{a}\end{array}$ & $2.20 \pm 0.84^{a}$ \\
\hline
\end{tabular}

* One ewe lost her sponge during the insertion perond.

a,b,c The value having the same superscript in each column are not significantly different $(P<0.05)$ except $\mathrm{b}, \mathrm{c}$ in lambing rate $(P<0.01)$. 
method of MAKINO ${ }^{11)}$ and plasma LH was measured following the RIA method of NISWENDER et $a l^{12)}$.
Data on fertility were compared by chisquare analysis. Data on ovulation rate, number of follicles, prolificacy, wastage of

Table 2. Relationships between ovarian status and lamb production in ewes treated with saline, GnRH or anti-PMSG following MAP sponge and PMSG during the non-breeding season

\begin{tabular}{|c|c|c|c|c|c|}
\hline \multirow{2}{*}{\multicolumn{2}{|c|}{ Group Ear-tag }} & \multicolumn{2}{|c|}{ Ovarian status* } & \multirow{2}{*}{$\begin{array}{l}\text { No. of } \\
\text { lambs } \\
\text { born }\end{array}$} & \multirow{2}{*}{$\begin{array}{c}\text { Wastage of } \\
\text { eggs or } \\
\text { embryos }(\%)^{* *}\end{array}$} \\
\hline & & No. C.L. & No. follicles & & \\
\hline \multirow{11}{*}{$\begin{array}{c}\text { I } \\
\text { (Saline) }\end{array}$} & 63 & 2 & 0 & 0 & \\
\hline & 28 & 3 & 1 & 0 & \\
\hline & 25 & 8 & 0 & 2 & \\
\hline & 104 & 2 & 0 & 0 & \\
\hline & 196 & 1 & 2 & 0 & \\
\hline & 106 & 2 & 0 & 1 & \\
\hline & 41 & 2 & 3 & 0 & \\
\hline & 32 & 2 & 0 & 0 & \\
\hline & $1-10$ & 8 & 0 & 0 & \\
\hline & 136 & 3 & 0 & 0 & \\
\hline & $\begin{array}{l}\text { Mean } \pm \text { SD } \\
\text { (or Total) }\end{array}$ & $3.30 \pm 2.54^{\mathrm{a}}$ & $0.60 \pm 1.07^{\mathrm{b}}$ & 3 & 90.9 \\
\hline \multirow{11}{*}{$\begin{array}{c}\text { II } \\
(\mathrm{GnRH})\end{array}$} & 40 & 4 & 0 & 2 & \\
\hline & 51 & 3 & 1 & 0 & \\
\hline & 44 & 2 & 1 & 0 & \\
\hline & 116 & 3 & 5 & 3 & \\
\hline & 200 & 2 & 1 & 1 & \\
\hline & 60 & 5 & 1 & 0 & \\
\hline & 125 & 5 & 1 & 2 & \\
\hline & 55 & 2 & 1 & 2 & \\
\hline & 197 & 1 & 2 & 0 & \\
\hline & 195 & 1 & 1 & 0 & \\
\hline & $\begin{array}{l}\text { Mean } \pm S D \\
\text { (or Total) }\end{array}$ & $2.80 \pm 1.48^{\mathrm{a}}$ & $1.40 \pm 1.35^{\mathrm{b}}$ & 10 & 64.3 \\
\hline \multirow{11}{*}{$\begin{array}{c}\text { III } \\
\text { (Anti- } \\
\text { PMSG) }\end{array}$} & $0-10$ & 2 & 1 & 0 & \\
\hline & 122 & 5 & 1 & 0 & \\
\hline & 120 & 2 & 0 & 1 & \\
\hline & 18 & 1 & 0 & 0 & \\
\hline & 30 & 2 & 2 & 2 & \\
\hline & 137 & 2 & 0 & 0 & \\
\hline & 33 & 1 & 1 & 0 & \\
\hline & 43 & 1 & 0 & 0 & \\
\hline & 45 & 2 & 4 & 0 & \\
\hline & 36 & 3 & 1 & 0 & \\
\hline & $\begin{array}{l}\text { Mean } \pm \text { SD } \\
\text { (or Total) }\end{array}$ & $2.10 \pm 1.20^{\mathrm{a}}$ & $1.00 \pm 1.25^{b}$ & 3 & 85.7 \\
\hline
\end{tabular}

* Observed numbers of corpora lutea (C.L.) and follicles of $>5 \mathrm{~mm}$ in diameter by laparotomy 8 days after MAP sponge and PMSG treatments.

** 1 - (number of lambs born/number of ovulation for ewes conceiving at first estrus) $\times 100$. The proportions were significantly different among the groups $(P<0.05)$.

a,b The value having the same superscript in each group are not significantly different $(P<0.05)$. 
eggs or embryos and hormonal levels were subjected to analysis of variance, and differences were analyzed by Student's $t$-test ${ }^{13)}$.

\section{Results}

The results of fertility and prolificacy are summarized in Table 1. Two ewes did not show estrus and one ewe lost the sponge during the insertion period. These three ewes were therefore eliminated from the experimental data. A total of 56 ewes (group I: 18, group II: 19, and group III: 19) were inseminated. Pregnancy rates were not significantly different among the groups
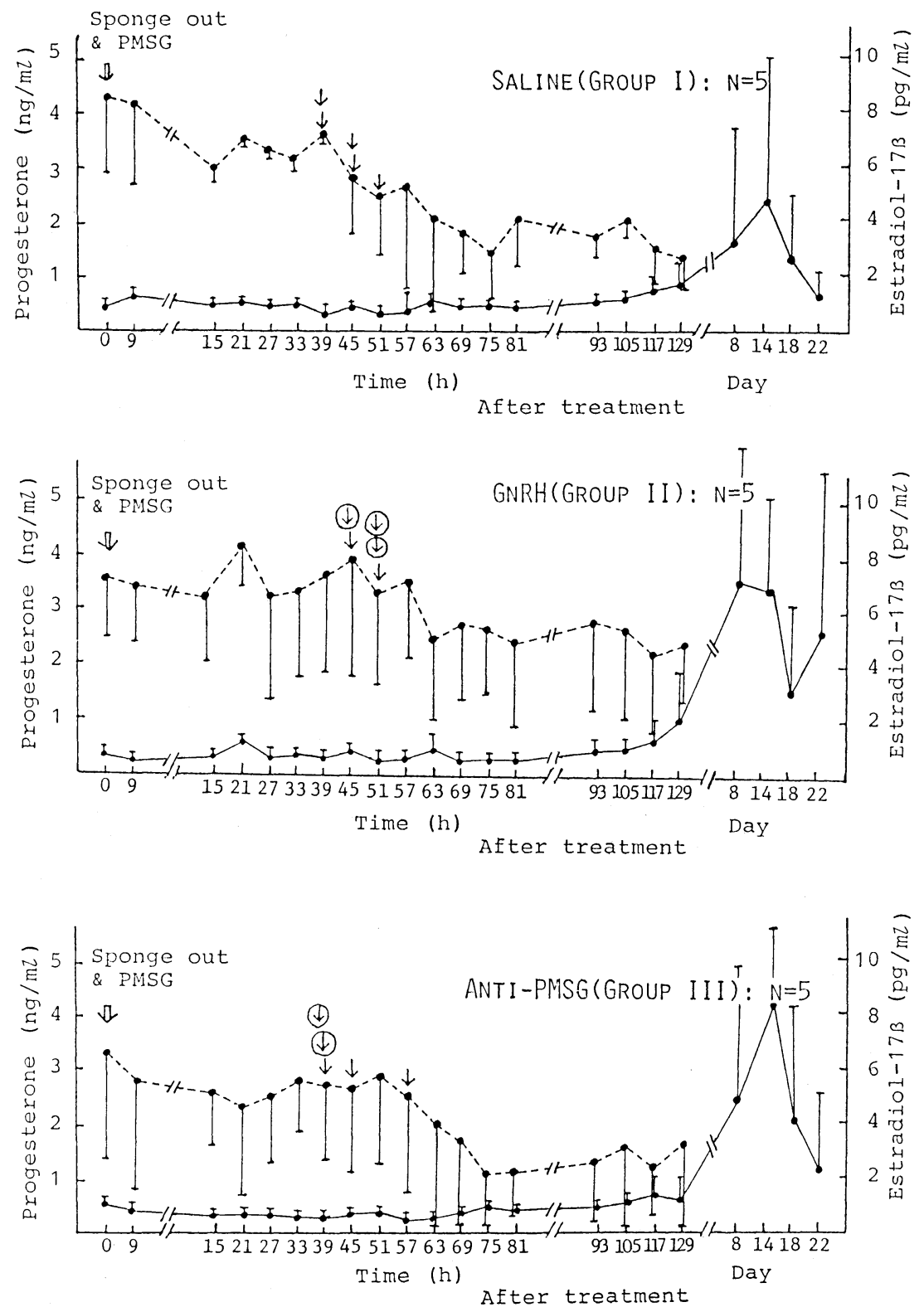

Fig. 1. Mean concentrations of plasma $P(-)$ and $E_{2}(\ldots)$ in the ewes of each group. The single arrow shows an estrous ewe and lambed ewes were indicated with " $(\downarrow)$ ". 
$\left(\chi^{2}=3,42\right.$, d.f. $\left.2,0.05<P<0.10\right)$, but lambing rate in group II $(57.9 \%)$ was significantly higher than those in both group I $(16.7 \%$ : $P<0.01, \chi^{2}=6.68$, d.f. 1) and group III (26.3\%: $P<0.05, \chi^{2}=3.89$, d.f. 1). There was no significant difference on prolificacy among the groups, but the mean prolificacy in group I was lower $(1.67 \pm 0.58)$ than these of groups II (1.91 \pm 0.83$)$ and III $(2.20 \pm 0.84)$ in spite of the highest ovulation rates shown in Table 2. All laparotomized ewes ovulated (Table 2). However, mean numbers of ovulations $(3.30 \pm 2.54,2.80 \pm 1.48$ and $2.10 \pm 1.20$ for groups I, II and III, respectively) and those of follicles of $>5 \mathrm{~mm}$ in diameter $(0.60 \pm$ $1.07,1.40 \pm 1.35$ and $1.00 \pm 1.25$ for groups
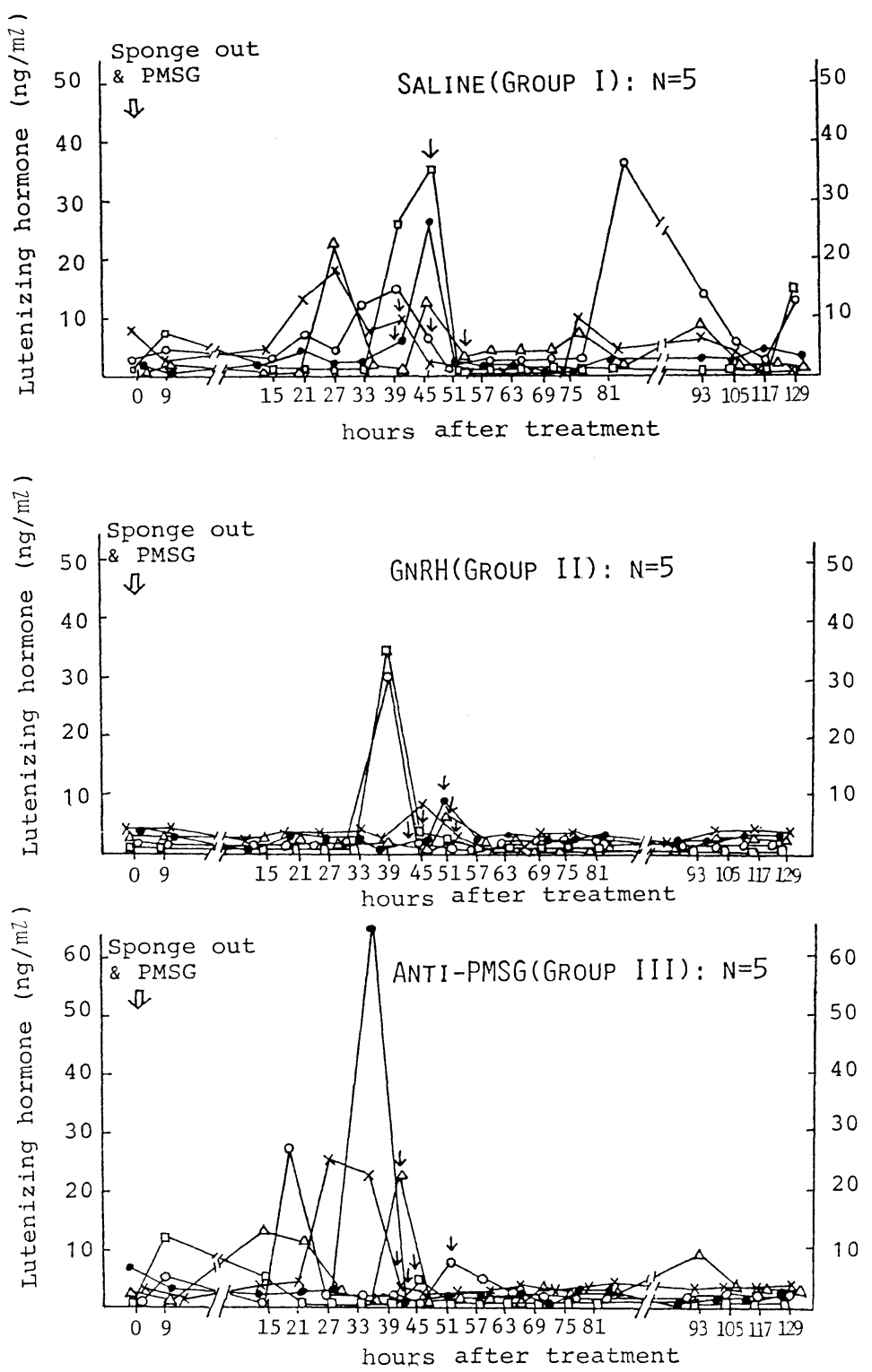

Fig. 2. Patterns of plasma LH concentrations in each ewe treated with GnRH or anti-PMSG following MAP sponge and PMSG treatments. The arrow indicates an estrus detected. 
I, II and III, respectively) were not significantly different among the groups. Proportions of wastage of eggs or embryos were extremely high in all groups $(64.3-90.9 \%)$ and were significantly different $\left(P<0.05: \quad \chi^{2}=\right.$ 7.34, d.f. 2) among the groups. Treatment with GnRH significantly $(P<0.025)$ decreased the wastage proportion in ewes $(64.3 \%)$ as compared with that in saline-treated ewes (90.9\%).

Plasma concentration of $\mathrm{E}_{2}$ and $\mathrm{P}$ in each group were shown in Fig. 1 . The $P$ levels increased from $129 \mathrm{~h}$ after PMSG treatment in each group. Patterns of the mean concentrations of plasma $\mathrm{P}$ were similar among the groups except day 22 in group II. Plasma $\mathrm{P}$ level at day 22 in lambed ewes $(3.33 \pm 2.21 \mathrm{ng} / \mathrm{m} l)$ was higher than that of not-lambed ewes $(0.82 \pm 1.00 \mathrm{ng} / \mathrm{ml})$, though there was no significant difference. Plasma $\mathrm{E}_{2}$ level in group III declined after the anti-PMSG injection. The minimum level $(1.38 \pm 1.08 \mathrm{pg} / \mathrm{ml})$ at $75 \mathrm{~h}$ after PMSG treatment was significantly different $(P<0.05)$ from the groups I $(3.00 \pm 1.95 \mathrm{pg} / \mathrm{m} i)$ and II $(4.88 \pm 2.15 \mathrm{pg} / \mathrm{ml})$. The range between the anti-PMSG injection and minimum level of plasma $E_{2}$ in each ewe was $24-36 \mathrm{~h}$. As shown in Fig. 2, a clear elevation in basal $\mathrm{LH}$ concentration was observed in GnRH-treated ewes, but in other groups of ewes, early $\mathrm{LH}$ elevations were observed prior to the onset of estrus.

\section{Discussion}

The present results indicate the that a single intramuscular injection of $150 \mu \mathrm{g} \mathrm{GnRH}$ at the time of the induced estrus significantly increased lambing rate. Lowered fertility in seasonally anestrous ewes treated with a progestin and PMSG was reported to be associated with abnormally early secretion and peak of $\mathrm{LH}$ following treatment ${ }^{1)}$. In the present study, GnRH was injected in ewes between 0 and $6 \mathrm{~h}$ after the onset of estrus. It may be argued that $\mathrm{LH}$ secretion induced by exogenously administered $\mathrm{GnRH}$ could not be distinguished from the spontaneous LH secretion. However, the present results and other reports ${ }^{3-5,14,15)}$ have indicated that the $\mathrm{LH}$ release and progesterone secretion induced by $\mathrm{GnRH}$ injection could be attributed to the newley formed corpus luteum. Since a clear elevation in basal $\mathrm{LH}$ concentrations was observed in GnRH-treated ewes, whereas in ewes of groups I and III, abnormal LH elevations occurred early before or after the onset of estrus. More frequent blood collections would be required in order to precisely detect a peak of $\mathrm{LH}$ surge.

For the route of administration $\mathrm{GnRH}$ has been applied intravenously ${ }^{14-17)}$ or intramuscularly ${ }^{3,5,16,18)}$ with a single large dose $(100-300 \mu \mathrm{g})$ and continuous infusion or multiple intravenous injections for several days with a small dose $(0.25-50 \mu \mathrm{g})^{4,6,19-22)}$. However, it appears that continuous or multiple intravenous injections are not recommended for practical purposes. Several workers have claimed that the use of $\mathrm{GnRH}$ without other hormonal pretreatment, like progestin, failed to induce an estrus ${ }^{14)}$ and normal luteal function ${ }^{23-25)}$. It has been also indicated that injection of $\mathrm{GnRH}$ alone significantly decreased the height of the peak and the total amount of $\mathrm{LH}$ released in ewes as compared with those in animals pretreated with either estradiol or PMSG and in natural estrous ewes ${ }^{14,15)}$. The present study has shown that a fertile estrus which was induced by a single intramuscular injection of $150 \mu \mathrm{g}$ $\mathrm{GnRH}$ combined with MAP sponge and 
PMSG pretreatments, and the normal luteal function was also resulted in a significantly low wastage of eggs or embryos in the GnRH-treated ewes. A dose of $150 \mu \mathrm{g} \mathrm{GnRH}$ used in the present study was chosen according to the report of FosTER and CRIGHTON $^{14)}$. HARESIGN and LAMMING ${ }^{15)}$ reported that ovulation with the subsequent induction of luteal function was produced in ewes treated with PMSG $24 \mathrm{~h}$ before an injection of GnRH. The intervals between PMSG and GnRH injections in the present study were varied in each ewes depending on the time of estrus after PMSG treatment with a range of 24-54 h. It has been also reported that $\mathrm{GnRH}$ may induce release of follicle stimulating hormore (FSH) in vitro and in vivo ${ }^{26-28)}$ and that more follicular development took place in GnRH-treated ewes ${ }^{24)}$. In the present study, the number of follicles of $>5 \mathrm{~mm}$ in diameter at the 8th day after PMSG treament was higher in GnRH-treated ewes than that in other two groups (Table 2 ), though there was no significant difference. Determination of the interval between the PMSG injection and a single GnRH injection would be a subject for future study to clarify the relationship among follicular development, ovulation and fertility.

Anti-PMSG injection was also performed in estrous ewes between 0 and $6 \mathrm{~h}$ after the onset of estrus, as well as the GnRH injection. The effect of anti-PMSG on fertility was not found in the present study, although KUMMER et $a l .{ }^{9)}$ showed in cattle that an injection of goat anti-PMSG serum $5 \mathrm{~h}$ after the first sign of estrus resulted in a higher number of ovulation and viable embryos. Because of the long half-life of PMSG (21 h in sheep ${ }^{28)}$ and $50-120 \mathrm{~h}$ in cattle ${ }^{30)}$ ), it frequently causes continued follicle stimulation after ovulation and results in persistent large follicles accompanied by high circulating estrogen levels ${ }^{31,32)}$. The injection of goat or sheep anti-PMSG serum at estrus in sheep ${ }^{7)}$, goats ${ }^{8)}$ and heifers ${ }^{\text {})}$ pretreated with PMSG decreases the number of large follicles observed and estradiol-17B concentration after ovulation. The effect of rabbit anti-PMSG on decrease of estradiol-17B concentration was observed in the present study, but it could not improve the fertility. The number of ovulation also decreased in the anti-PMSG-treated ewes. The present results of the anti-PMSG accord with the report of ARMSTRONG et al. ${ }^{8)}$ in goats, they suggested that the premature luteal failure in PMSG-treated animals is not due to persistence of PMSG in the circulation during the post-ovulatory periods but to the failure of the endocrine normalities, during the pre-ovulatory period. In these respects, it is likely that the injection of $\mathrm{GnRH}$, but not the anti-PMSG could explain a higher fertility in the present study.

As shown in Table 2, proportions of embryo wastage were extremely high (64-91\%). The present data were in accord with other reports showing that the rate of embryo and lamb wastages increased as ovulation rate increased. A significantly low proportion of the wastage in the $\mathrm{GnRH}$ injected group may be caused by $\mathrm{LH}$ release during the pre-ovulatory period followed by the normal luteal function. The normal range of early embryonic mortality were $17-25 \%$ in natural mating systems during the breeding season ${ }^{10)}$ and $55-62 \%$ in synchronized ewes during the non-breeding season $^{2)}$. As compared with the figures, the higher rates of egg or embryo wastage in the present study are likely to be influenced by frequent blood collections and surgical procedures to observe the ovarian status. 
It is concluded that a single intramuscular injection of $150 \mu \mathrm{g} \mathrm{GnRH}$ at the onset of induced estrus, with a progestin vaginal sponge and PMSG in seasonally anestrous ewes, was effective for increasing the fertility and the reduction of wastage of egg or embryo. This effect of $\mathrm{GnRH}$ could be attributed to the induction of the $\mathrm{LH}$ release during the preovulatory period.

\section{Acknowledgements}

The authors wish to thank the staff of the Tawa Field Station, Shibechya, Hokkaido, Japan for their cooperation in the conduct of the study. We are indebted to Dr. S. H. LANGFORD, The Upjohn International Ltd., Australia, Takeda Industrial Co., Japan and Teikoku-zoki Co., Japan for the supply of MAP sponges, Conceral and Anti-PMSG, respectively. Finally, thanks are also due to Prof. M. MIYAKE and co-workers for RIA of steroid hormones.

\section{References}

1) Echternkamp, S. E. \& D. D. Lunstra: Theriogenology, 10, 65, 1978.

2) Lunstra, D. D. \& R. K. Christenson: J. Anim. Sci., 53, 458, 1981.

3) Lofstedt, R. M. \& P. G. Eness: Theriogenology 18, 119, 1982.

4) MCleod, B. J., W. Haresign \& G. E. Lamming: J. Reprod. Fert., 65, 215, 1982.

5) Kinser, A. R., M. F. Gibson, D. L. Vincent, N. S. Scheffrahn \& D. J. Kesler: Theriogenology, 19, 449, 1983.

6) Wright, P. J., I. J. Clarke \& J. K. Findlay: Aust. Vet. J., 60, 254, 1983.

7) Bindon, B. M. \& L. R. PiPeR: Theriogenology, 8, $171,1977$.

8) Armstrong, D. T., B. G. Miller, E. A. Walton, A. P. Pfitzner \& G. M. Warnes: In Embryo Transfer in Cattle, Sheep and Goats. (Shelton, J. N., A. O. Trounson, N. W. Moore \& J. W. JAmes eds.) pp. 8, Aust. Soc. Reprod. Biol. Press, 1982.

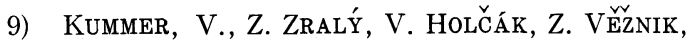
J. SćHLEgelová \& K. HRUSKa: Theriogenology, 14, 383, 1980.

10) Smith, J. F., P. V. Pattray \& K. T. Jagusch: In Proc. Wld. Congr. Sheep and Beef Cattle Breeding. (Barton, R. A. \& W. C. Smith eds.)
1, 375, Wld. Congr. Sheep and Beef Cattle Breeding Society, Inc., 1982.

11) Makino, T.: Folia Endocr. Japon., 49, 629, 1973.

12) Niswender, G. D., L. E. Reichert, JR., A. R. Midgley, JR. \& A. V. NAlbandov: Endocrinology, 84, 1166, 1969.

13) Steel, R. G. D. \& J. H. TORRIE: Principles and Procedures of Statistics (STEEL, R. G. D. \& J. H. Torrie eds.), McGraw-Hill Book Co., New York.

14) Foster, J.P. \& D. B. CRighton: Theriogenology, 2, 87, 1974 .

15) Haresign, W. \& G. E. Lamming: J. Reprod. Fert., 52, 349, 1978.

16) Arimura, A., L. Debeljuk, H. Matsuo \& A. V. Schally: Proc. Soc. Exp. Biol. Med., 139, 851, 1972.

17) Wheaton, J. E., S. E. Recabarren \& M. A. Mullet: J. Anim. Sci., 55, 384, 1982.

18) Reeves, J. J., A. Arimura, A. V. Schally, C. L. KaAgt, T. W. BeCk \& J. M. Casey: J. Anim. Sci., 35, 84, 1972.

19) Skubiszewski, B., F. Przekop, E. Wolińska, E. STUPNicka, B. WróblewSKa \& E. DomańsKi: Anim. Reprod. Sci., 4, 269, 1982.

20) MCneilly, A. S., M. Hunter, R. B. LAND \& H. M. Fraser: J. Reprod. Fert., 63, 137, 1981.

21) Mcnatty, K. P., K. Ball, M. GibB, N. Hudson \& D. C. Thurley: J. Reprod. Fert., 64, 93, 1982.

22) Wheaton, J. E. \& M. A. Mullet: J. Reprod. Fert., 64, 325, 1982.

23) Crighton, D. B., J. P. Foster, W. Haresign \& S. A. ScotT: J. Reprod. Fert., 44, 121, 1975.

24) Haresign, W., J. P. Foster, N. B. Hatnes, D. B. Crighton \& G. E. Lamming: J. Reprod. Fert., 43, 269, 1975.

25) Shareha, A. W., W. R. Ward \& K. Birchall: J. Reprod. Fert., 46, 331, 1976.

26) Crighton, D. B.: J. Physiol., London, 226, 69. 1972.

27) Crighton, D. B. \& J. P. Foster: J. Endocr., 55, Xxiii, 1972.

28) Jonas, H. A., L. A. Salamonsen, H. G. Burger, W. A. Chamley, I. A. Cumming, J. K. Findlay \& J. R. CoDING: Endocrinology, 92, 862, 1973.

29) Mcintosh, J. E., R. M. Moor \& W. R. Allen: J. Reprod. Fert., 44, 95, 1975.

30) Schams, D., Ch. Menzer, F. Schallemberger, B. Hoffman, J. Hahn \& R. HahN: In Current Topics in Veterinary Medicine I. (SREEnAN, J. M. ed.) pp. 122, M. Nijhoff: The Hague, 1978. 
31) Saumande, J.: J. Endocr., 84, 425, 1980.

32) Monniaux, D., D. Chupin \& J. Saumande: Theriogenology, 19, 55, 1983.

33) Casida, L. E., C. O. Woody \& A. L. Pope: J.
Anim. Sci., 25, 173, 1969.

34) Edey, T. N.: Anim. Breed. Abstr., 37, 173, 1969.

(Received January 9, 1984)

\title{
非繁殖季節に括いて発情, 排卵誘起された雌羊の受胎率に 及ぼす GnRH および抗 PMSG 注射の効果
}

\author{
福井 豊・武中慎治・百目鬼郁男* - 小野 斉 \\ (带広畜産大学畜産学部肉畜增殖学教室 *農水省畜産試験場繁殖第 2 研究室)
}

\begin{abstract}
非繁殖季節 (4 5 月) 亿西いて, 発情, 排卵を誘起し ホルモン $(\mathrm{LH})$ を RIA 法により測定した。 た成熟サフォーク種雌羊, 59 頭の受胎率に及济す $\mathrm{GnRH}$ および 抗 PMSG 注射の効果を比較検討した。発情, 排 畉は $60 \mathrm{mg}$ 合成黄体ホルモン (MAP) を含を腔内スポ ンジ (以下 MAP スボンジと記す)を 9 日間臸内深部へ 挿入し, その除去時に 750 IU PMSG (妊馬血清性性腺刺 激ホルモン)を投与することにより誘起した。

MAP スポンジ除去と PMSG の処置後 5 日間, 6 時 間毎に発情観察を行ない, 発情雌羊には $2 \mathrm{~m} l$ 生理食塩 水 (対照区: I 群), $3 \mathrm{~m} l(150 \mu \mathrm{g}) \mathrm{GnRH}$ 溶液 (コンセラ ール: II 群) または $2 \mathrm{~m} l$ 希釈ウサギ抗 PMSG 血清 (III 群: PMSG 750 IU に相当する力価を中和する抗体価をも つ）を筋肉注射した。そして，発情発見後 9 時間目に $0.2 \sim 0.25 \mathrm{~m} l$ の新鮮原精液を頸管外口部内に人工授精 し, 受胎率 (70 90 日妊娠率拈よび分娩率), 多産率を比 較した。各群 10 頭につき PMSG 処置後 8 日目に開腹

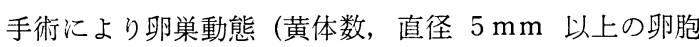
数）を観察，記録した。さらに，各群 5 頭において，処 置後 22 日間継続的汇頸静脈より採血し, 血漿中プロジ エステロン $(\mathrm{P})$, エストラジオール $17 \beta\left(\mathrm{E}_{2}\right)$ および黄体

各群にお战る授精頭数/処置頭数は 18/19 (I 群), 19/20 (II 群) そして 19/20 (III 群) であった。妊娠率 (I 群: 27.8\%, II 群: $57.9 \%$ III 群: $36.8 \%$ ) は各群間に有意差 は見られなかったが，分婏率は II 群 $(57.9 \%)$ が他の 2 群よりも有意汇 (I 群: $16.7 \%, P<0.01$, III 群: $26.3 \%$, $P<0.05$ ) 高かった。多産率は I 群で低かった (I 群: 1.67 \pm 0.58 , II 群: $1.91 \pm 0.83$, III 群: $2.20 \pm 0.84)$ が有意 差は認められなかった。処置後 8 日目の黄体数および卵 胞数についても, 各群間 (I 群: $3.30 \pm 2.54,0.60 \pm 1.07$, II 群: $2.80 \pm 1.48,1.40 \pm 1.35$, III 群: $2.10 \pm 1.20,1.00$ \pm 1.25 ) 亿有意差はなかった。GnRH 注射区 (II 群) に おいて，排卵卵子または胚の死減率は有意に $(P<0.05)$ 低かった (I 群: 90.9\%, II 群: 64.3\%, III 群: 85.7\%)。 また, 抗 PMSG 注射により血漿中 $\mathrm{E}_{2}$ 濃度は短時間飞 低下したが，受胎率への効果は認められなかった。以上 の結果から，非繁殖季節において MAP スポンジと PMSG で発情を誘起した雌羊に $150 \mu \mathrm{g} \mathrm{GnRH} \mathrm{を} 1$ 回筋肉注射することにより, 受胎率の向上が認められ た。
\end{abstract}

